\title{
FIBER REINFORCED SOY-BASED POLYURETHANE SPRAY FOAM INSULATION. PART 1: CELL MORPHOLOGIES
}

\author{
Mustafa Khazabi, Ruijun Gu, and Mohini Sain* \\ Environmentally friendly polyurethane (PU) spray foam insulation was \\ prepared by substituting petrochemical polyol with soy-based polyol. The \\ effects of adding wood fiber and water on the cell morphologies were \\ studied. Cell size increased with the presence of wood fiber, but it \\ decreased with an increase of water $\left(\mathrm{H}_{2} \mathrm{O}\right)$. Still, shorter fiber decreased \\ in foam density but increased in cell size and open cell content.
}

Keywords: Biofoam, Insulation; Polyurethane; Spray foam; Soybean oil; Wood fiber

Contact information: Faculty of Forestry, University of Toronto, Toronto, ON, M5S 3B3 CANADA

*Corresponding author email: m.sain@utoronto.ca

\section{INTRODUCTION}

Most sprayed polyurethane (PU) foams are used in the construction/building area (Bomberg and Kumaran 1999). PU spray foam insulation prevents air leakage and retains effective energy (Moore and Ference 1998). Compared to traditional insulation, sprayedin-place PU foam quickly expands up to 100 times its original liquid size in seconds to create an airtight environment by sealing and filling each cavity, crevasse, void, and cap, which overcomes some of the causes of energy loss in a building. This also improves indoor air quality by blocking harmful outside irritants and eliminates the particles that are emitted and develop from fibrous and dusty insulations. It provides a healthier indoor environment. This sealed envelope can also improve sound abatement because airborne noise can no longer seep through the walls (Falke et al. 2001). In addition, PU spray foam also has high R-value compared to common insulation materials (Anon, Honeywell technical document), which will lower heating cost in cooler regions of Canada (Anon, Dow technical documents). Still, PU insulation adheres well to almost any material, especially wood and steel studs (Lohman 2005).

Biodegradable foams lower society's dependence on fossil fuels and have drawn attention in construction building industry to develop more environmentally friendly practices (Pollack 2004). Biofoam is a new, entirely sustainable and biologically degradable polymer made from renewable bio-sources (Meyer 2011). Bio-based polyol has been prepared from biobased epoxidized vegetable oils (Tan and Chow 2010). Still, biomass consumes less energy associated with the energy required for the fabrication process (Anon, Omni Tech International 2010) and reduces the carbon footprint by absorbing greenhouse gas during the plant lifecycle (Sleeckx 2006). The large output of soybean oil in North America is motivating the use of soy-based polyol (Soyol) (USDA 2011; Allen 2009).

Soy-based PU spray foam is popular due to its good quality, superior adhesion, and fast dry-time. Soyol is derived from soybean oils. Soy oils come from soybeans. The 
soy has achieved a higher yield due to advances in its biotechnology. According to the U.S Department of Agriculture (USDA) figures for 2010, 93\% of all of soybeans produced in USA are genetically engineered for herbicide tolerance (USDA 2010), and $70 \%$ of the global productions are biotechnical soybeans (James 2008). The vast majority of genetically modified soybean oils are used for affordable soyol production by adding hydroxyl groups at the unsaturated sites (Monteavaro et al. 2005; Petrović et al. 2005).

Soyol, since its invention, has been used in various PU foam applications due to its renewability (Sherman 2007). Natural fibers, which also are rich in hydroxyl groups, can be introduced for reinforcement (Silva et al. 2010; Gu et al. 2010; Bledzki et al. 2001) to give a better biodegradation (Silva et al. 2010). Therefore, it would be interesting to study the cell morphologies of PU spray foam in presence of wood fiber.

\section{EXPERIMENTAL}

\section{Materials and Methods}

Soy-based Polyol (Soyol)

Soyol, which is rich in triglycerides structures, was prepared from soybean oil by adding hydroxyls at the unsaturated sites. Low odor Soyol ${ }^{\circledR} 2102$ was donated by Urethane Soy Systems (Volga, South Dakota, USA). It is the $5^{\text {th }}$ generation of polyol made using soybean oil. Its bio-renewable content is as high as $98 \%$, as reported by ASTM D 6866. Its hydroxyl number was $63 \mathrm{mg} \mathrm{KOH} / \mathrm{g}$ according to ASTM D4274-99 with the viscosity of $2181 \mathrm{cps}$ at $25^{\circ} \mathrm{C}$.

\section{Isocyanate}

Polymeric diphenylmethane-diisocyanate (PMDI) having 31.5\% NCO content was donated by Huntsman and used to produce sprayed foams. Its functionality was 2.7, as provided by the supplier.

\section{Wood pulp fiber}

Steam explosion pulp of trembling aspen (high energy, 8 bar pressure) was received from Forintek Canada Corp (Point-Claire, Quebec, Canada). This air-dried industrial aspen Chemical Thermal Mechanical Pulp (CTMP) was cut and screened into 20-35, 35-70, 70-100, 100-140, 140-200, and 200-325 mesh size ranges, respectively. Six select fibers were introduced into PU spray foams as natural filler. This unbleached CTMP fiber imparts PU biofoam a dark-brown color.

\section{Catalysts}

Diamine was used as a foaming catalyst, which was received from Sigma Chemical Company. Tertiary amine donated by Air Products and Chemicals, Inc. (Allentown, Pennsylvania, USA) was used as a gelling catalyst.

\section{Surfactant}

Polysiloxane family based surfactant was used to achieve superior cell structures; these were donated by Air Products and Chemicals, Inc. 


\section{Blowing agent}

Distilled water was used as a blowing agent to generate foams; this was prepared in our lab.

\section{Foam Preparation and Evaluation}

PU spray foams were prepared by a free-rise method with the formulations shown in Table 1. The amount of pulp fiber used was in terms of 100 parts of soyol. The soyol was manually mixed with the additives (catalysts, surfactant and $\mathrm{H}_{2} \mathrm{O}$ ) for 5 mins under ambient temperature, and then PMDI was added and mixed for another 20 seconds. The resultant mixture was quickly transferred into a mold for foaming to get neat PU spray foams. For the reinforced PU spray foams, wood fiber was pre-mixed with soyol for 20 min to wet completely. The process was the same as the preparation of neat foam. Finally, all the PU spray foams were kept at the room temperature and well post-cured overnight.

Obviously, the amount of $\mathrm{H}_{2} \mathrm{O}$ can be expected to have significant influences on the cell performances. In this study, the amount of $\mathrm{H}_{2} \mathrm{O}$ was set in the range of 4.7 to 8.0php (parts per 100 parts) of soyol. When a lower amount (less than 4.7php) of $\mathrm{H}_{2} \mathrm{O}$ was used, neat PU foams were shrinkable. Oppositely, neat PU foams would collapse when the amount of $\mathrm{H}_{2} \mathrm{O}$ was over 8.0php. From Fig. 1a-c, more $\mathrm{H}_{2} \mathrm{O}$ helped create a smooth, plump appearance. With the addition of wood fiber, the foam shrank even further, as can be seen by comparing with Fig. $1 \mathrm{~b}$ (no fiber) to Fig. 1d (20php fiber) with the same $4.7 \mathrm{php} \mathrm{H}_{2} \mathrm{O}$ content. Therefore, the amount of $\mathrm{H}_{2} \mathrm{O}$ was adjusted to $6.7 \mathrm{php}$ in order to get acceptable fiber reinforced foams as shown in Fig. 1e. Meanwhile, the foaming and gelling time was extended from 20 seconds up to several minutes when wood fiber was introduced, according to our observations. In addition, longer curing time was required as more fiber was added. It demonstrated that wood fiber in particular for CTMP fiber had a delaying effect on urethane reaction.

Table 1. Formulations for PU Spray Foam Insulation

\begin{tabular}{llll}
\hline \multirow{2}{*}{ Materials } & & \multicolumn{2}{c}{ Parts by weight, php } \\
\cline { 3 - 4 } & & Neat PU spray foam & PU-Fiber spray foam \\
\hline Soyol & Soyol $(2102$ & 100 & 100 \\
Catalyst & Diamine & 1.33 & 1.33 \\
Surfactant & Tertiary amine & 2.0 & 2.0 \\
Blowing agent & Polysiloxane & 0.67 & 0.67 \\
PMDI & $\mathrm{H}_{2} \mathrm{O}$ & $4.7 ; 5.3 ; 6.7 ; 8.0$ & 6.7 \\
Wood fiber & $\mathrm{NCO}$ index & 120 & 120 \\
\hline
\end{tabular}

$\dagger$ Six select fibers were formulated 

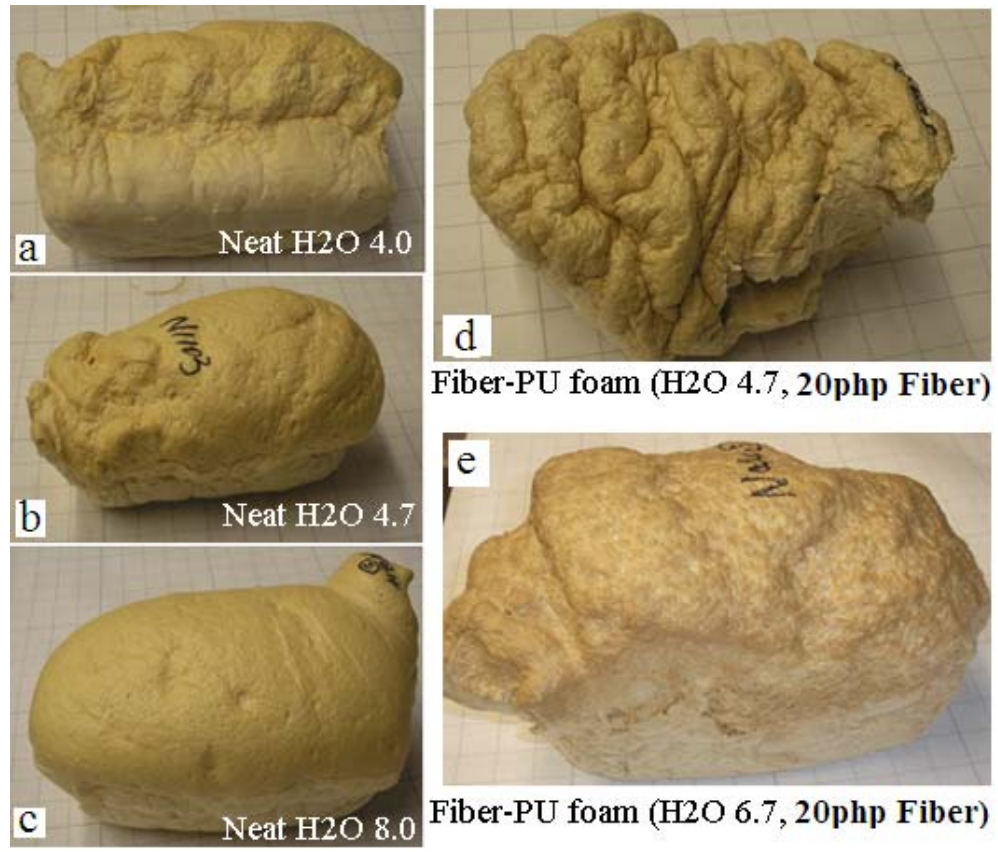

Fiber-PU foam (H2O 4.7, 20php Fiber)

Fig. 1. Evaluations of PU spray foams

\section{Fiber Quality Analysis (FQA)}

The length of fiber particles and their distribution were measured by Fiber Quality Analyzer (OpTest equipment Inc. Hawkesburg, Canada). The fiber count was over 5000.

\section{Morphologies of PU Spray Foam}

All the foams were conditioned at $23{ }^{\circ} \mathrm{C}$ and $45 \%$ relative humidity, and then the foam slabs were extracted by cutting with a saw, followed by polishing with a belt sander (Model 31-710, Rockwell international, Pittsburgh, USA). The size of grit was 120. The length, width, and thickness were measured after polishing. The thickness is along the foam rise direction.

Open cell content measurement and foam density

10 small specimens $(3 \mathrm{~cm} \times 3 \mathrm{~cm} \times 3 \mathrm{~cm})$ were used to get the foam densities according to ASTM D1622-09, and then the open cell percentage was determined by a Quantachrome Instruments Ultrapychometer 1000 (Boynton Beach, FL) according to ASTM D6226-05 under $23^{\circ} \mathrm{C}$ and $45 \%$ relative humidity.

Scanning electron microscope (SEM) investigation

Sample stub with thin foam slab was surface metalized by a sputter coating (BOT $341 \mathrm{~F}$ ) with evaporated gold (in 4nm thickness), and then was carried out by SEM (Hitachi S-2500, Hitachi High Technologies Inc., Tokyo, Japan) at an acceleration voltage of $15 \mathrm{kV}$.

The cell morphologies were statistically analyzed by ImageJ including feret diameter, feret distribution, and the regularity of cell (round). 


\section{RESULTS AND DISCUSSIONS}

FQA

It has been reported that natural fiber can influence the performances of PU microfoams (Bledzki et al. 2001). However, PU spray foam is different from the reported PU foams due to its quick expansion and fast dry-time. In this study the effects of fiber concentration and fiber size in particular for fiber length on the sprayed foams were investigated. The length distributions of 6 classified fibers are shown in Fig. 2. The 6 select fibers had roughly the same width by cutting the same original fiber source. However, the select fibers had distinguished length distributions and exhibited different average fiber sizes. Fibers in high mesh had short length and narrow distribution, such that they were more like particles rather than fibers. All these selected fibers were introduced into sprayed PU foam reaction system after pre-wetting by soyol according to their fabrication process. The resultant foams were examined to reveal the changes in the cell morphological structures and performances.
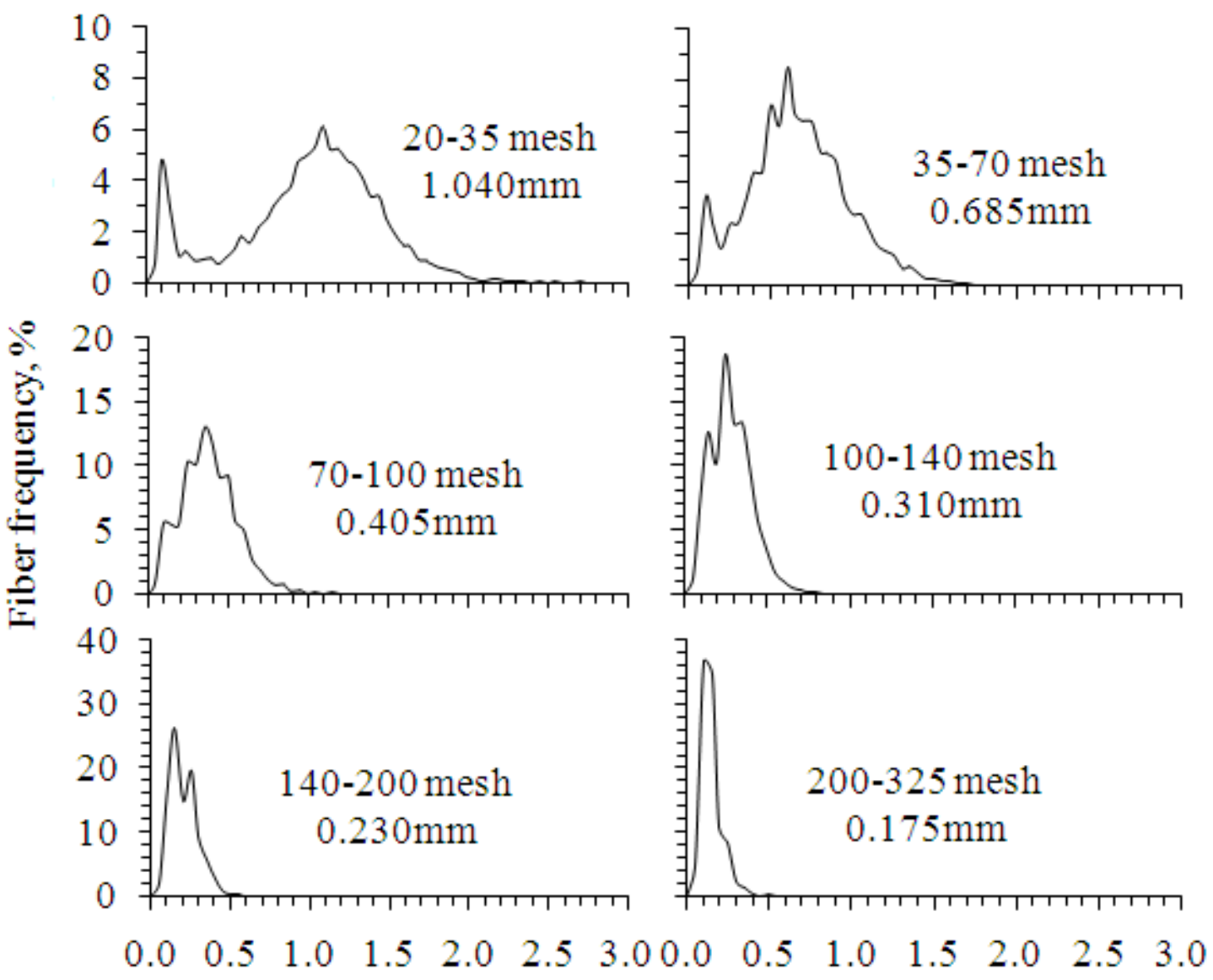

Fiber particle size, $\mathrm{mm}$

Fig. 2. Average fiber length and distribution of select fibers 


\section{Morphological Structures of PU Spray Foams}

Effect of $\mathrm{H}_{2} \mathrm{O}$ content on cell structures

In general the amount of $\mathrm{H}_{2} \mathrm{O}$ dominated the cell structures of water-blown PU foams because the $\mathrm{CO}_{2}$ gas was released from the reaction between water and $-\mathrm{NCO}$ groups of PMDI. But the influence of gas expansion should be neglected if the foam comprised mostly open cells and avoided "exoterm" problems, such as foam coreburning. In addition, the effect of the moisture of polyol could also be neglected due to its very low amount reported by its supplier (max $0.01 \%)$.

The effects of $\mathrm{H}_{2} \mathrm{O}$ on foam density and cell structures are demonstrated in Fig. 3. In this study, the densities for the neat PU foams varied depending on the amount of water as blowing agent. Figure 3 shows the variation in density and open cell content of the neat PU foams with 4.7-8.0php $\mathrm{H}_{2} \mathrm{O}$, which was based on the weight of soyol. With the increase of $\mathrm{H}_{2} \mathrm{O}$ from 4.7 to $8.0 \mathrm{php}$, the densities of the neat PU foams decreased from 40.9 to $24.5 \mathrm{~kg} / \mathrm{m}^{3}$. This finding corresponded to the results of $\mathrm{H}_{2} \mathrm{O}$-blown foams based on polyester polyol (Thirumal et al. 2008; Li et al. 2006). However, there was some deviation in cell structures as the open cell content decreased from $90.6 \%$ of $4.7 \mathrm{php}$ $\mathrm{H}_{2} \mathrm{O}$ presented to $87.3 \%$ as $6.7 \mathrm{php} \mathrm{H}_{2} \mathrm{O}$ was introduced. After that the open cell content rebounded to $90.2 \%$ again. This change was caused by the un-uniform distribution of $\mathrm{H}_{2} \mathrm{O}$ molecules through the whole foam. In any case, the neat PU spray foam can achieve maximum closed cells in the presence of 6.7php $\mathrm{H}_{2} \mathrm{O}$.

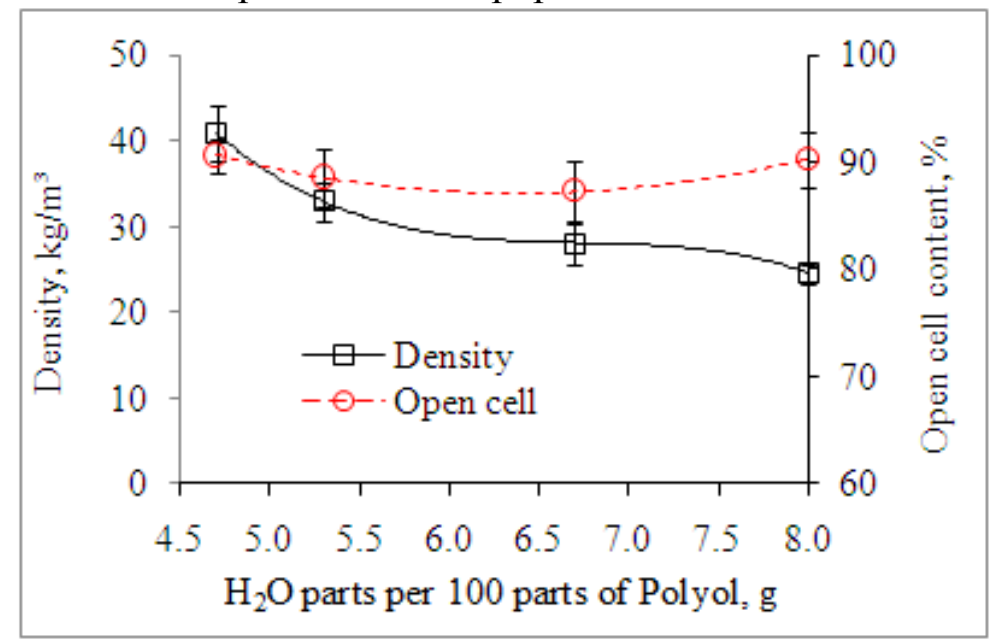

Fig. 3. Effect of $\mathrm{H}_{2} \mathrm{O}$ on foam density and open cell content

Figure 4 shows the cell size distributions of the neat PU foams with different $\mathrm{H}_{2} \mathrm{O}$ concentration. The distribution of cell size was narrowed on the downward side as more $\mathrm{H}_{2} \mathrm{O}$ was introduced. The decreased mean values of cells sizes have a linear relationship with an increase in $\mathrm{H}_{2} \mathrm{O}$ amount, as computed in Fig. 5. The cell feret diameter decreased from $401 \mu \mathrm{m}$ to $287 \mu \mathrm{m}$ when the amount of $\mathrm{H}_{2} \mathrm{O}$ increased from 4.7php to 8.0php. The decrease of cell size in biofoam with an increase of $\mathrm{H}_{2} \mathrm{O}$ content is opposite to the result of petrochemical PU foam reported by $\mathrm{Li}$ et al. (2006). The relationship of cell size to $\mathrm{H}_{2} \mathrm{O}$ content can be observed from the SEM images in Fig. 6. The cells became smaller and nonuniform as more $\mathrm{H}_{2} \mathrm{O}$ was introduced. This finding was corresponding to the decrease of cell irregularity as shown in Fig. 5. 


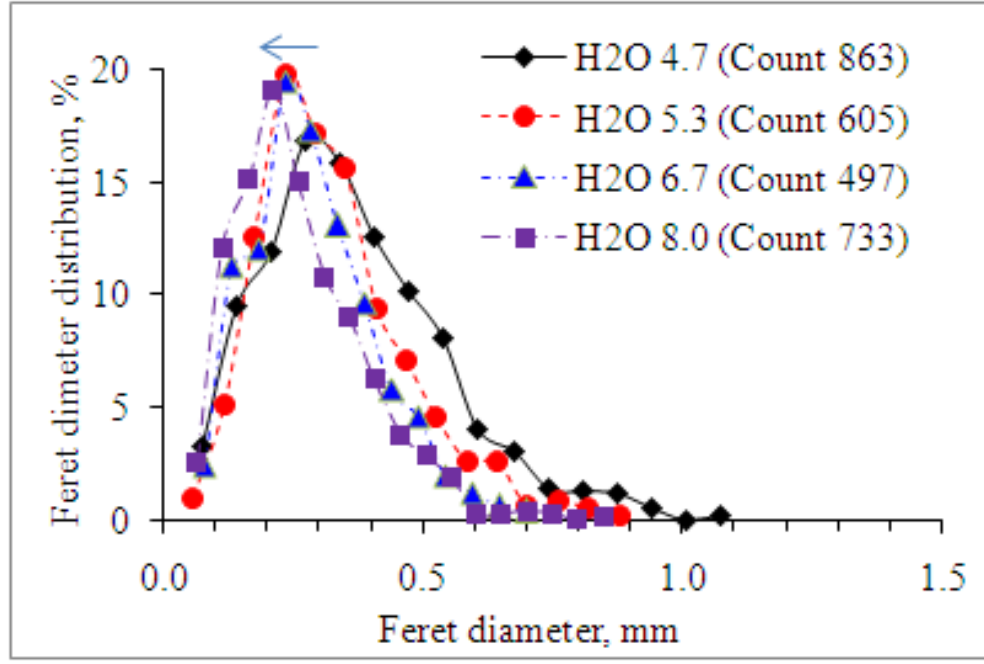

Fig. 4. Effect of $\mathrm{H}_{2} \mathrm{O}$ on cell size distribution

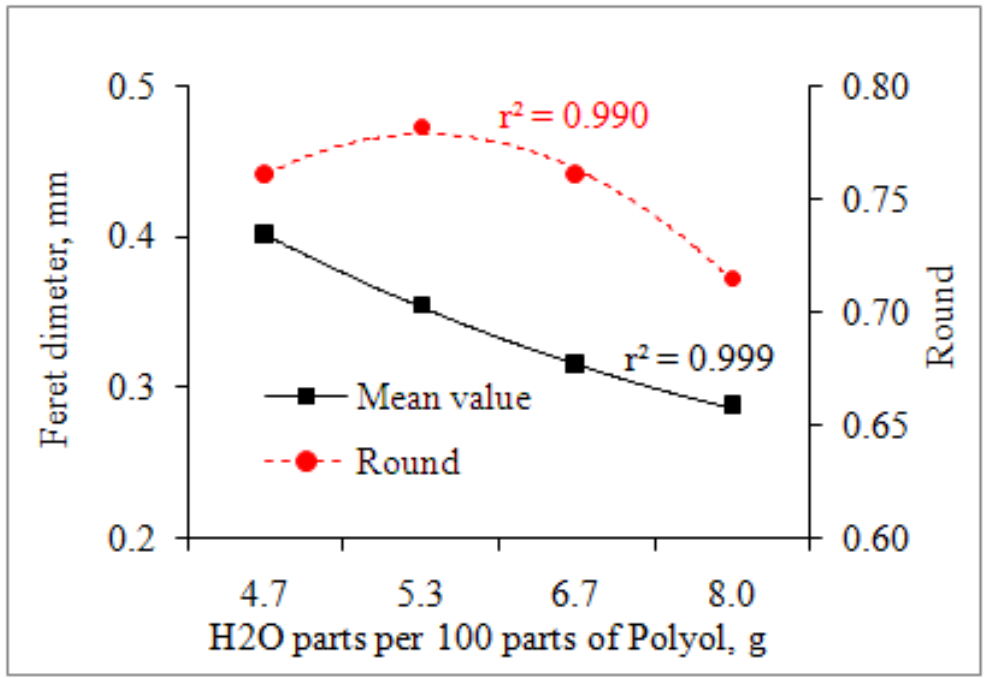

Fig. 5. Effect of $\mathrm{H}_{2} \mathrm{O}$ on cell structures

\section{Effect of wood fiber on cell structures}

Due to the fact that polyols contain a high content of hydroxyls groups and natural fiber are well wetted by polyols, the foam matrix was compatible with wood fiber, as shown in Figs. 7-1a and 8b. When 20php fibers were introduced into the foams, most fibers were framed in cell walls, as observed in Fig. 8 (a, c and d) due to the good compatibility between the fibers and polyols. Natural fibers were compatible with isocyanate. They may react to form units of urethane; the existence of secondary interactions of the fiber with polymer polyurethane may also be possible. Therefore, the surface of the fibers was well covered with the polymeric matrix. Only fewer long fibers were isolated and located in the pores, as shown in Fig. 7. Wood fiber had the most significant impact on the cell structures, typically to cell supports and cell windows. In addition, a woody color of pulp fibers was imparted to the fiber-reinforced PU spray foams with brownish-yellow color. This agglomeration of pulp fibers was clearly seen at the foam skin, as shown in Fig. 1e. 

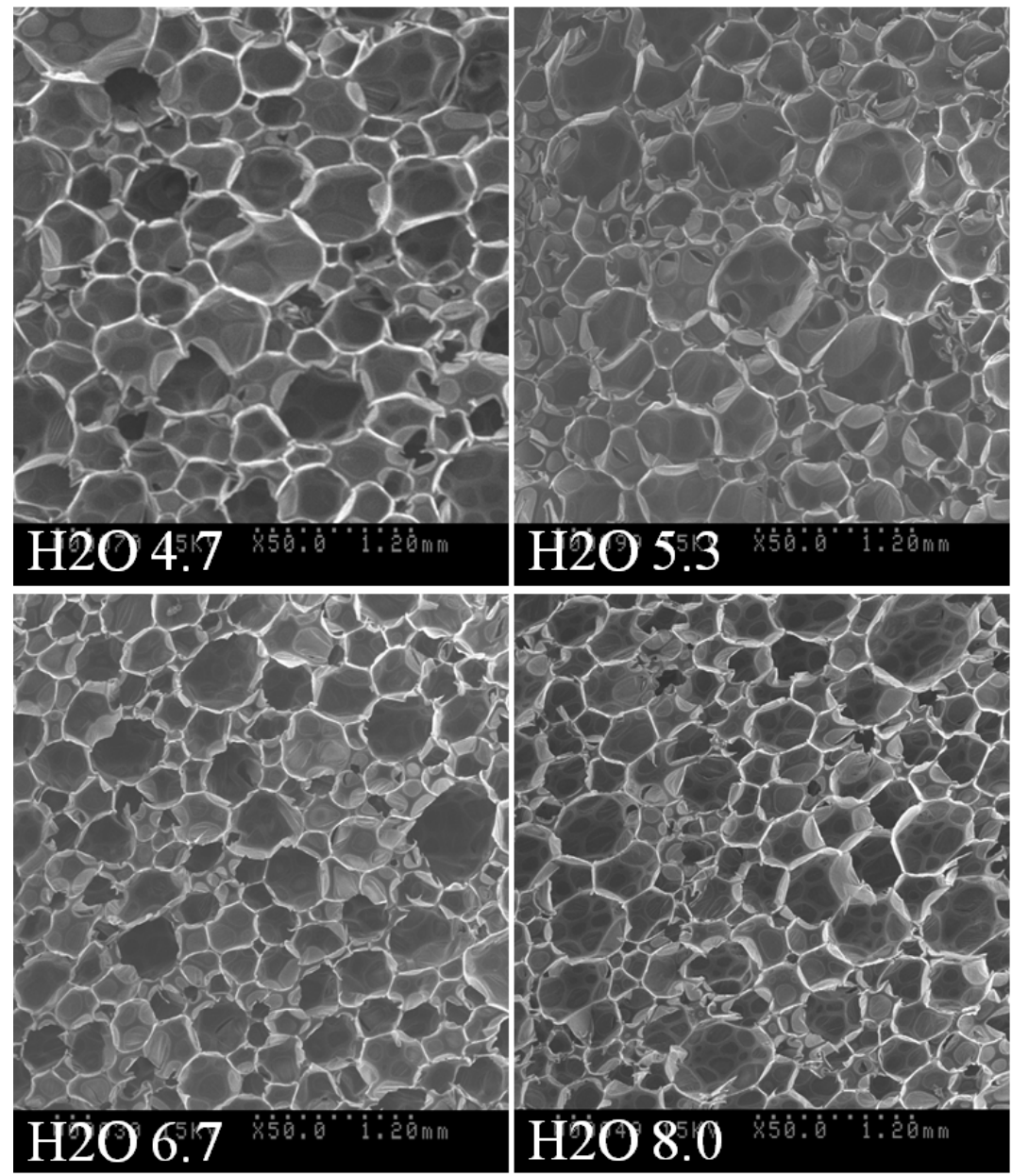

Fig. 6. SEM images of neat PU spray foam (50×)
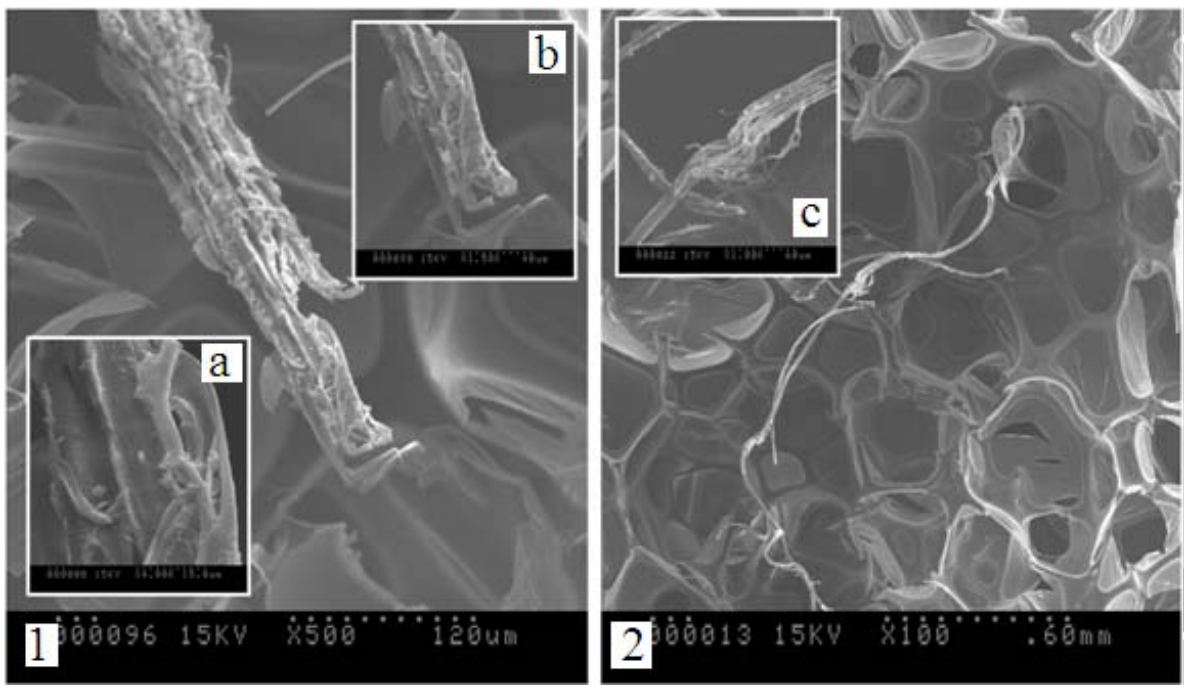

Fig. 7. Long fiber isolation in the cells

Khazabi et al. (2011). "Fiber soy foam. Pt. 1, morphol.," BioResources 6(4), 3757-3774. 3764 
PU has a good adhesion to wood (Wake 1978; Phanopoulos et al. 1999; Somani et al. 2003; Frihart 2005), especially at high hydroxyl content (Desai et al. 2003). Naturally, the fiber reinforced PU spray foam is also expected to have a good compatibility between the introduced fibers and the foam matrix to improve house insulation (Lohman 2005).
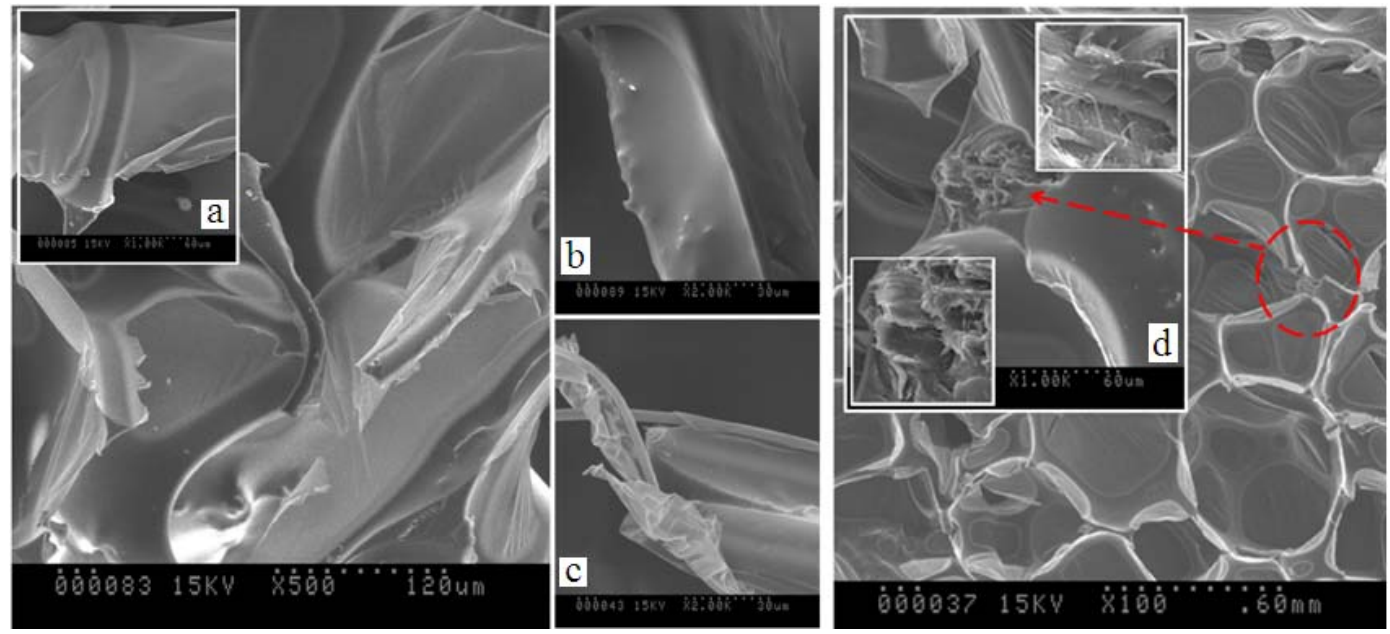

Fig. 8. Fiber framed in cell struts

\section{Effect of fiber concentration on cell structures}

The overall density of the foams increased steadily following an increase of wood fiber, as indicated in Fig. 10. The density of the fiber-reinforced foam achieved an increase of 3.8 times from $28 \mathrm{~kg} / \mathrm{m}^{3}$ of neat PU spray foam up to $136 \mathrm{~kg} / \mathrm{m}^{3}$ as $60 \mathrm{php}$ fiber was incorporated. A similar result was also obtained in polyester polyol foam (Silva et al. 2010). Incorporating of the right amount of fiber, such as 10-20php, the foam shrinkage can be prevented due to the support of stiffer fiber. Even though wood fiber was well wetted, some fiber destroyed cell structures high levels of fiber, as shown in Fig. 9.
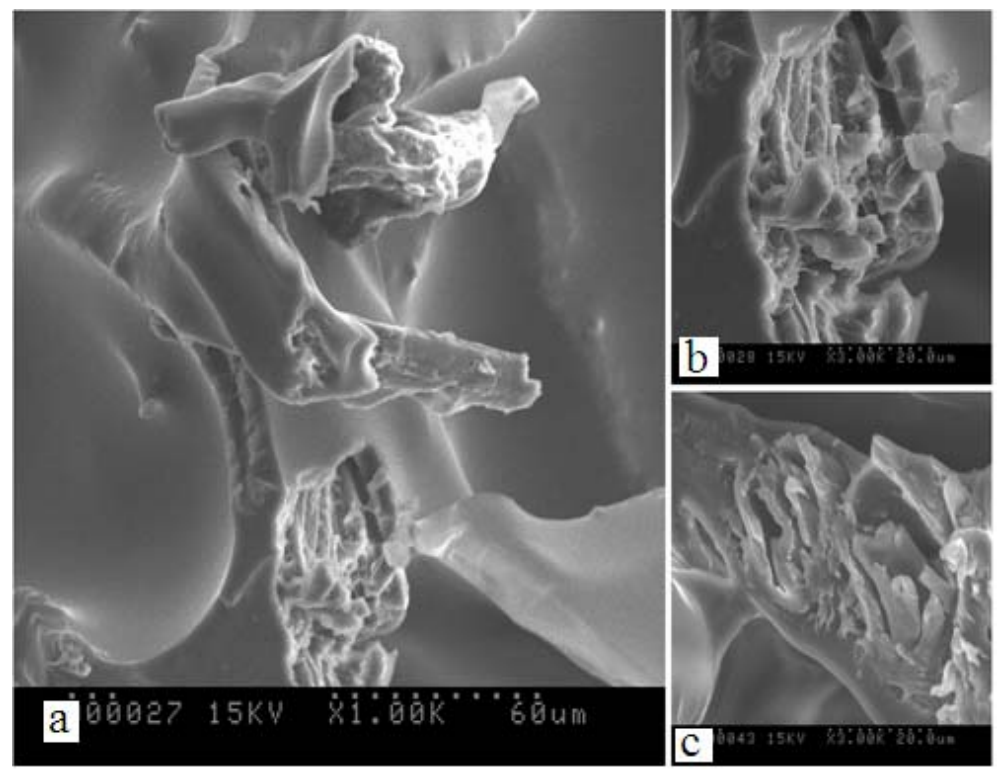

Fig. 9. Fiber existence in PU spray foam with high fiber loading 
From our observation, a typical effect of the addition of fiber into the foam mixture was an increase in viscosity. Foaming delay, induced by wood fiber, was also observed, halting the foam expansion and increasing the foam density (Silva et al. 2010). When more fiber was introduced, a much greater degree of time-delay-induced effects caused high foam density. This increase in density can be observed in Fig. 10. In addition to foam density, small amounts of fiber increased the open cell content from $87.3 \%$ of neat PU spray foam up to $91.3 \%$ for foam with $10 \mathrm{php}$ fiber; this was attributable to the high perforation behavior of wood fiber (Fig. 9a). However, the open cell content deceased to $85.5 \%$ when 60 php fiber was introduced (see Fig. 10) because some cell walls were overlapped into microvoids in a delayed foaming process (see Fig. 11c-f).

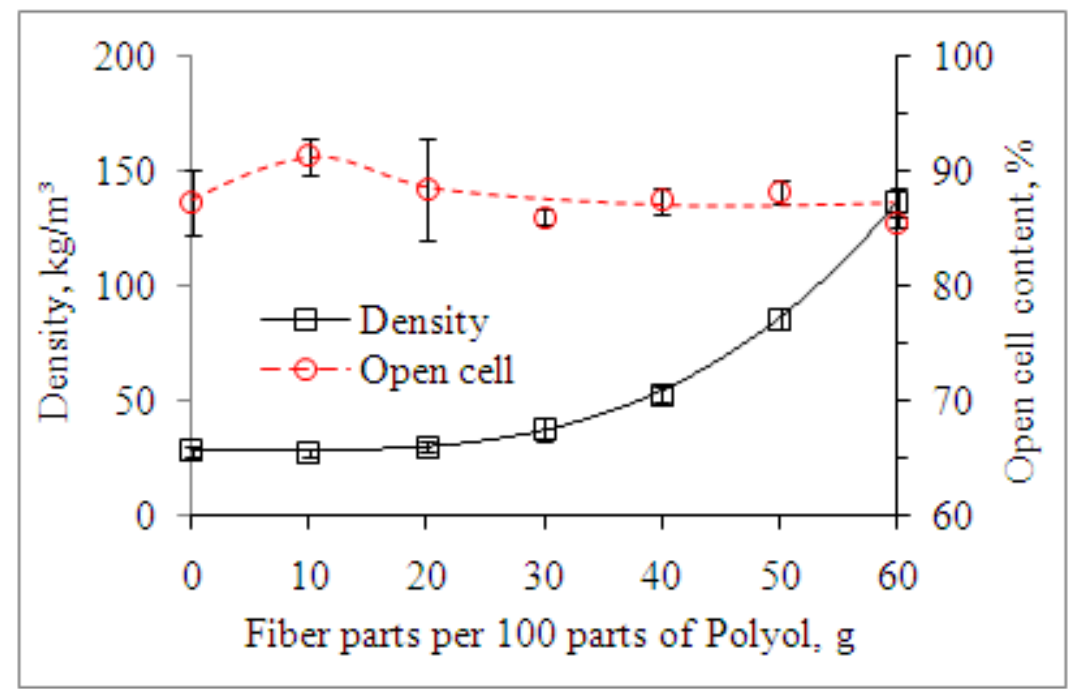

Fig. 10. Effect of fiber concentration on foam density and open cell content

The foam quality was dependent on the amount of fibers present because wood fiber can be framed into the cell structures, as described earlier. With more fibers employed, more cells became irregular and defective (Fig. 11) compared to the cells without fiber present (Fig. 6) (Silva et al. 2010). Stiff fiber also perforated the cell walls, which made it difficult to distinguish cells. It was hard to find an intact cell in the foam block in the presence of 60php fiber, as shown in Fig. 11f. In addition, more fiber introduced had increased the cell size (see Fig. 12). The distribution of cells also became inhomogeneous, which is shown in Fig. 13. Therefore, the increase in fiber content led to large irregular cells and a decrease of cell regularity (see Fig. 12) due to the gas releasing along the fiber axis.

The contribution of cell size in the direction of foam rise increased obviously and more cells were broken when more fiber was incorporated. With the increase of fiber concentration, the cell size increased from $314 \mu \mathrm{m}$ of neat PU foam to $655 \mu \mathrm{m}$ of $50 \mathrm{php}$ fiber reinforced foam, as shown in Fig. 12. This finding is contradictory to the finding in polyester polyol foams (Silva et al. 2010) because of different foam matrix, foaming technology, and the lack of auxiliary blowing agent in our case. This increase probably came from the cell breakage, which was caused by the continuous connected fibers, especially for high fiber loaded foam. 

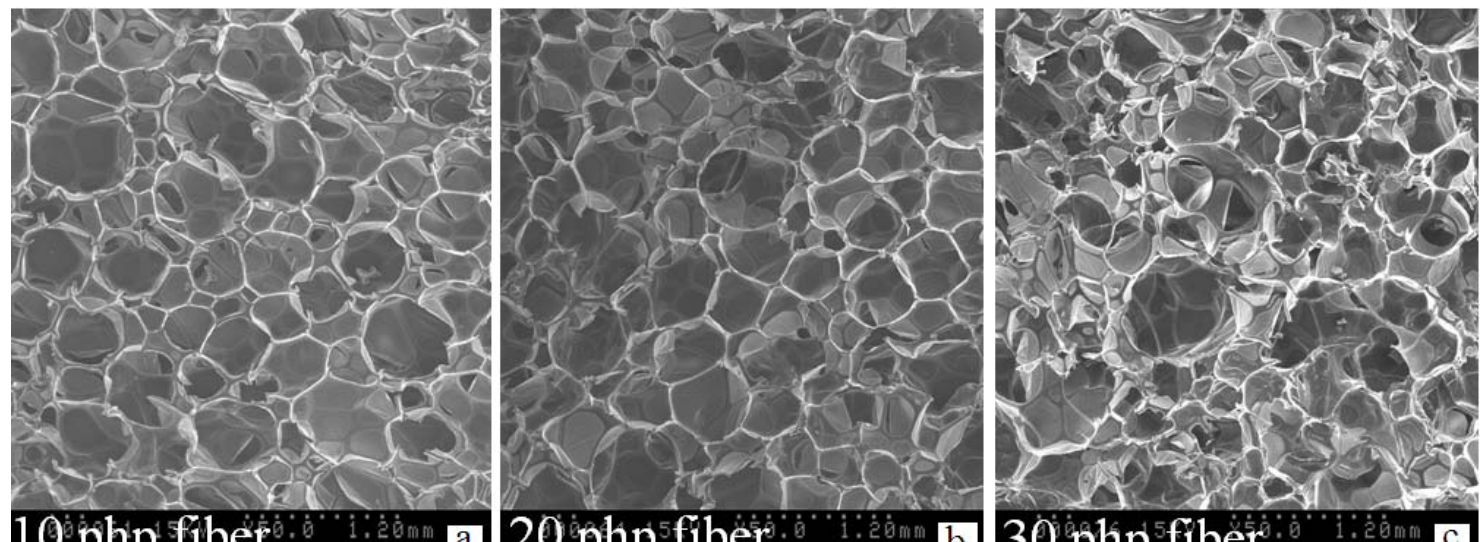
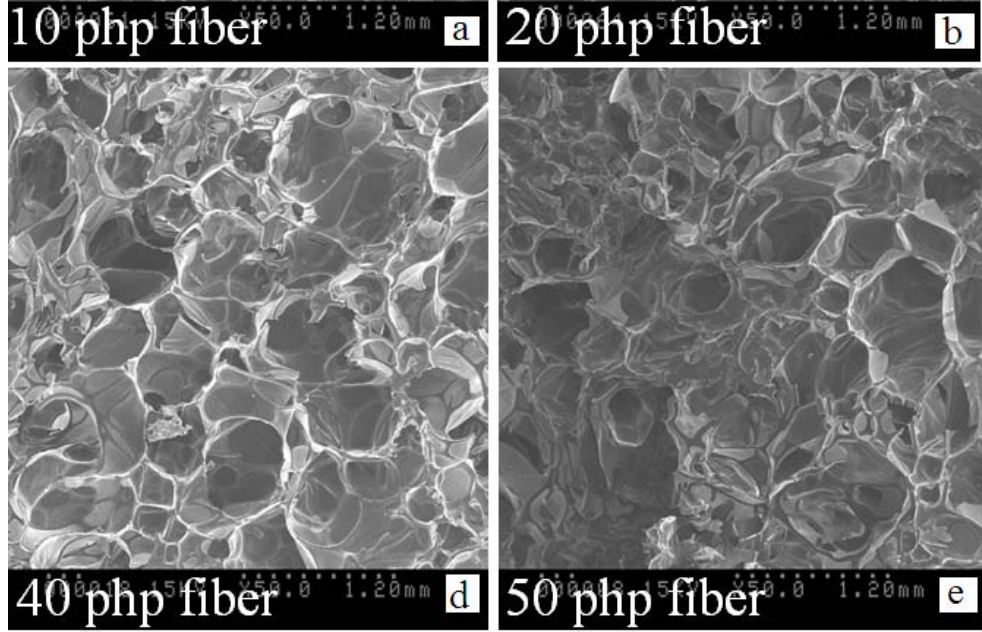
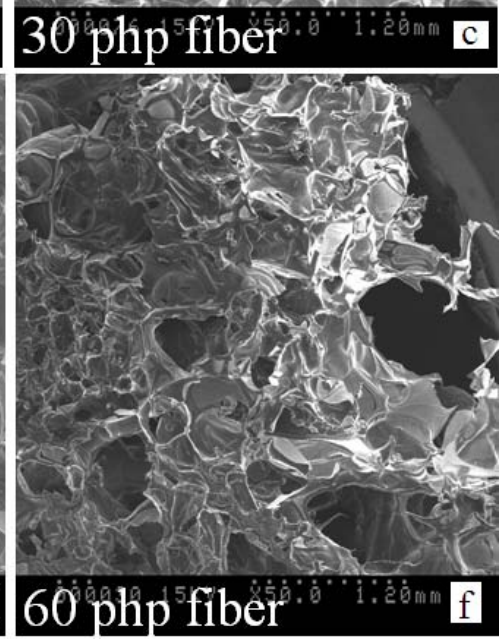

Fig. 11. SEM images of the fiber reinforced PU spray foams in different fiber concentration (50x)

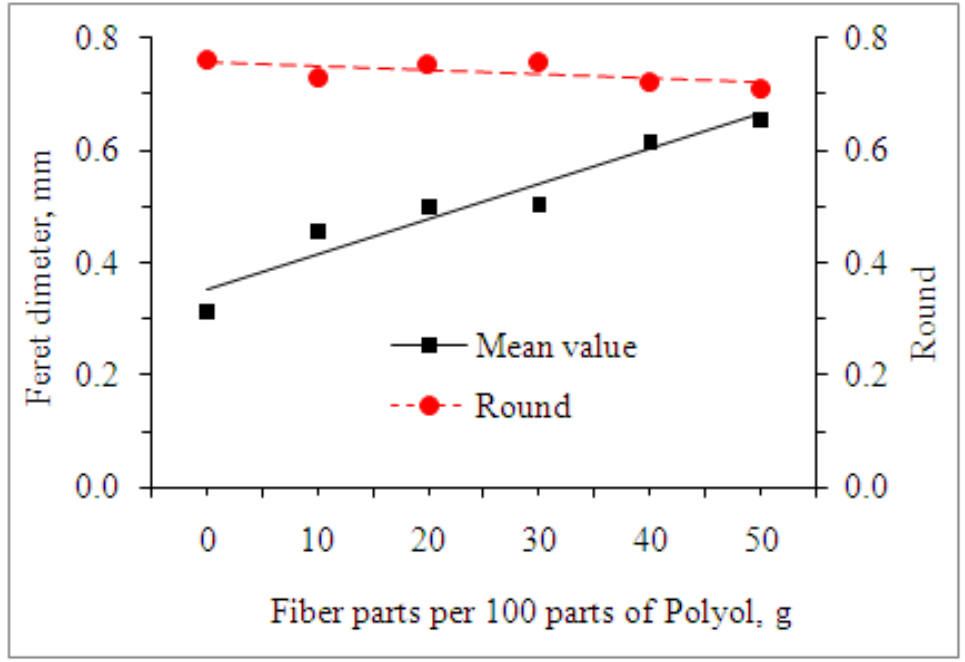

Fig. 12. Effect of fiber concentration on cell structures 


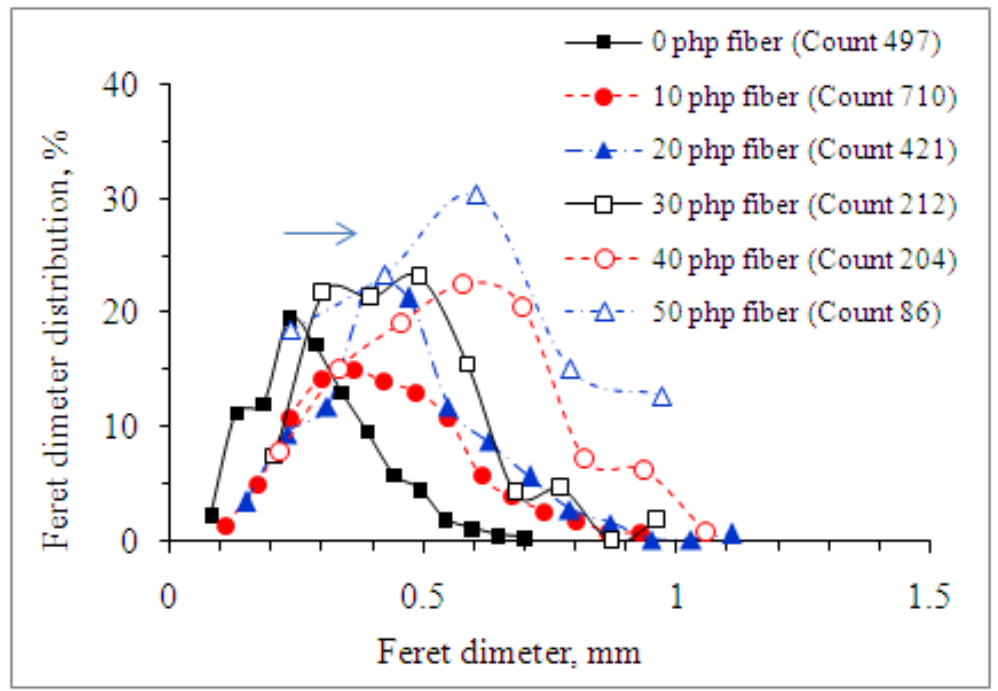

Fig. 13. Effect of fiber concentration on cell size distribution

Depth-of-field SEM images of the neat foam matrix (Fig. 14) clearly indicated polyhedral structures, which exhibited polygonal cell shapes (Bandyopadhyay-Ghosh et al. 2010) and three-dimensional cell wall structures (Fig. 14a) because of triglyceride molecule structure (Petrović 2008). Each polygonal cell-face was covered by a thin membranous window. The films are considerably thinner than the struts, as shown in Fig. 8a. In addition, the cell structure altered complex three-dimensional structures when fiber was introduced (Fig. 14b). Figure 14b shows a cross-section of broken struts, which were always formed at the junction of three windows (Dawson and Shortall 1982). The crosssectional profile for the struts were seen triangular and described as a hypocycloid of three cusps (Jones and Fesman 1965). However, the nodes were always formed by four struts from their SEM images. The three struts seen at each node in Fig. 14 were accompanied by a strut out of the plane of the micrograph.
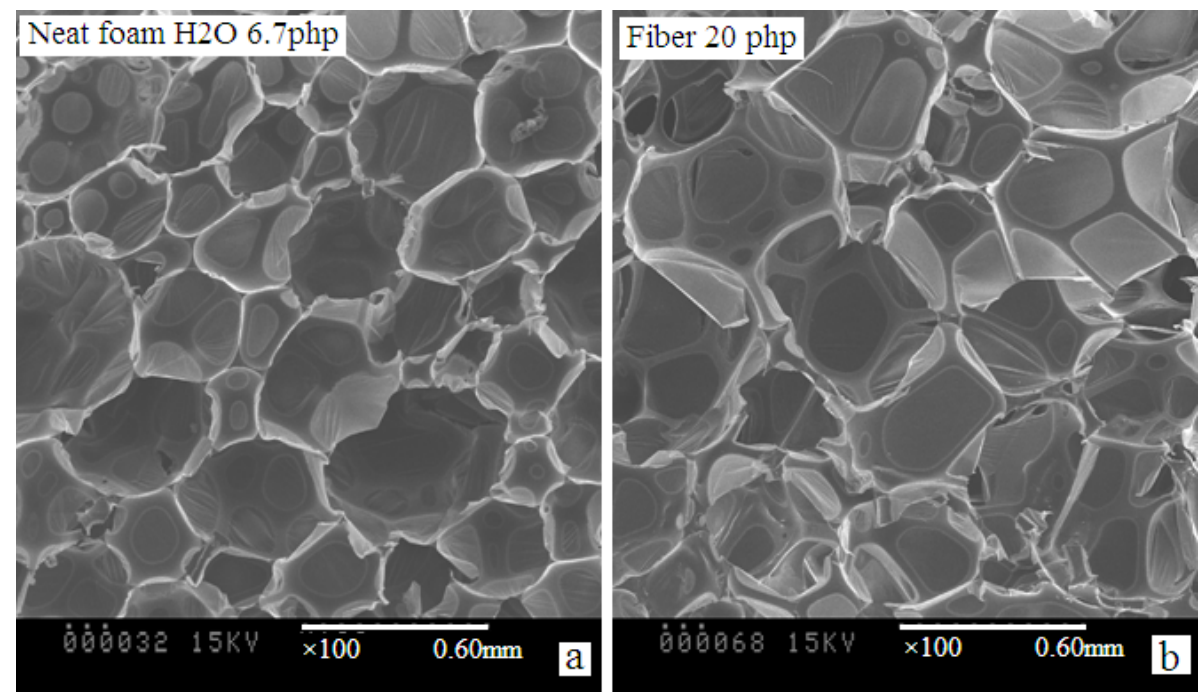

Fig. 14. Three-dimensional cell structures

a- neat PU spray foam; b- 20php fiber reinforced PU spray foam 
The fiber reinforced PU foams had more broken windows due to the stiffness of wood fiber from the observations of Figs. 6, 11, and 14. Furthermore, three-dimensional structures contributed the foams with good dimensional stability. In our case of predominantly open-cell PU foams (over 85\%), the open cells enabled the foam to breathe, ensuring cell gas equilibration to keep dimensional stability (Brown et al. 2010; Tylenda 1988).

\section{Effect of fiber size on cell structures}

The use of screened fibers as continuous threads in different oriented arrangements provided foams with different final properties. With the decrease of fiber size, the foam density reduced gradually from $32.7 \mathrm{~kg} / \mathrm{m}^{3}$ for $20-35$ mesh fiber-reinforced foam down to $27.4 \mathrm{~kg} / \mathrm{m}^{3}$ for those with use of $200-325$ mesh fiber, as shown in Fig. 15. This could be caused by the existence of much more smaller but numerous fiber particles. Unlike cell density, the open-cell content increased from $86 \%$ to $92 \%$ following the fiber size decreasing from $1.04 \mathrm{~mm}(20-35 \mathrm{mesh})$ to $0.175 \mathrm{~mm}(200-325 \mathrm{mesh})$. The small fibers can serve to increase cell amounts to large quantities by an enhanced heterogeneous nucleation (Ramesh et al. 1994; Rodrigue et al. 2001), which causes cellcell borders overlaps, leading to a minor increase of open cell content.

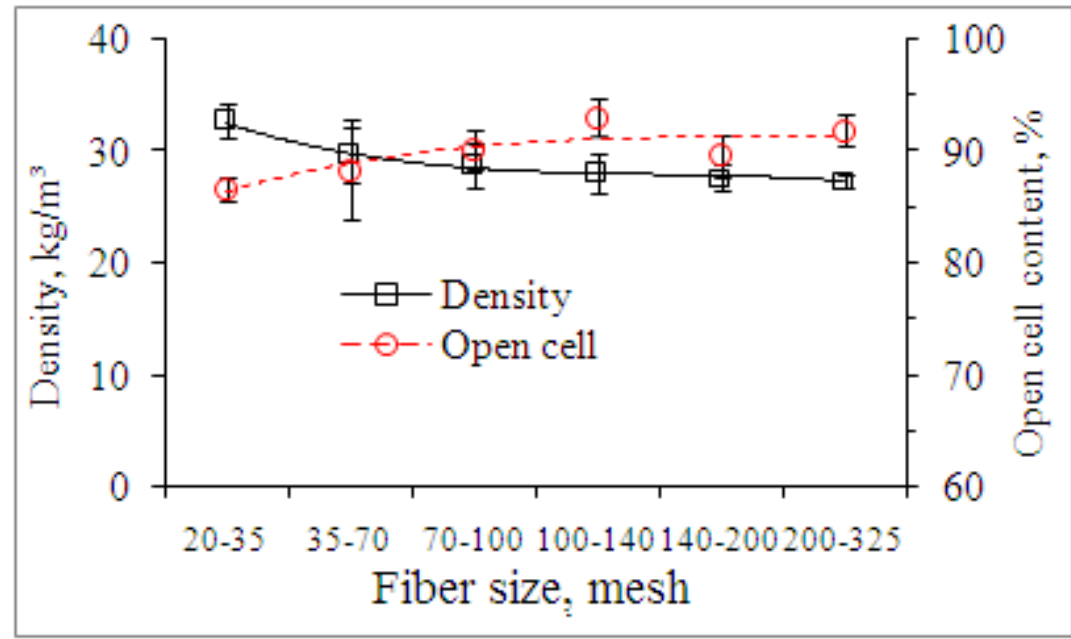

Fig. 15. Effect of fiber size on foam density and open cell content

The experimental measured cell size distributions for each sample were fitted in Fig. 16. With decreasing size of the fiber, the average cell size distribution increased. This deviation was exhibited clearly for the foam in a presence of $0.175 \mathrm{~mm}(200-325$ mesh) fiber.

Alternatively, the average cell diameter increased with decreasing fiber length, which was observed from Fig. 17. However, the effect of fiber size was not clear on the cell regularity. 


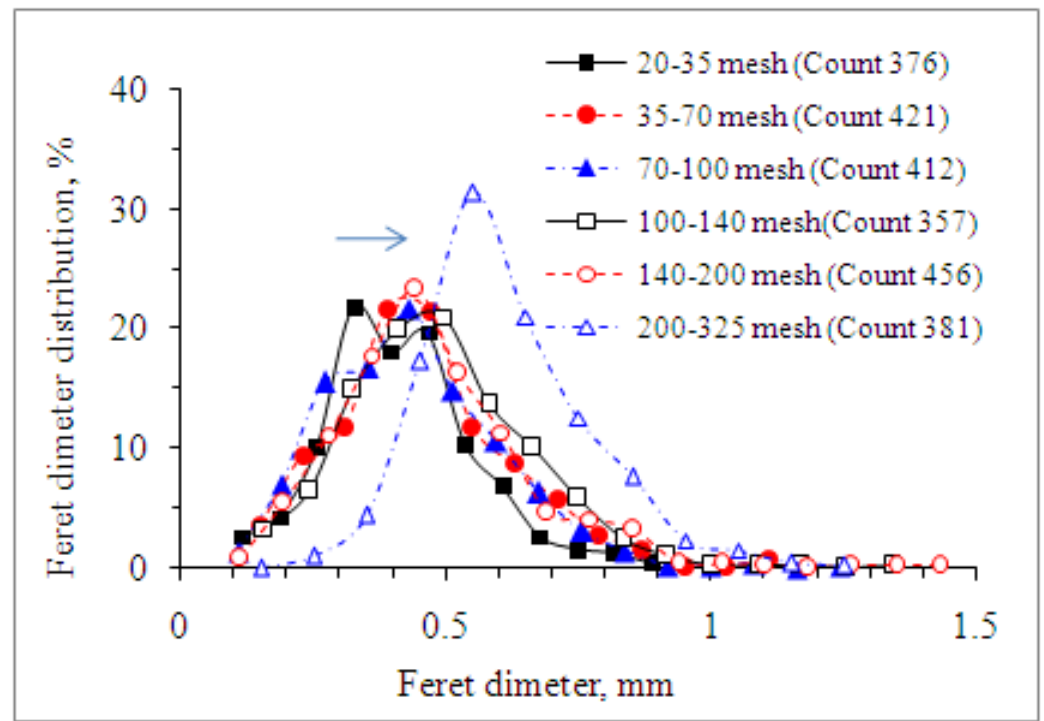

Fig. 16. Effect of fiber size on cell size distribution

Small fiber particles can accelerate the amount of foam cells as a nucleation agent (Ramesh et al. 1994; Rodrigue et al. 2001). The thickness of cell wall was expected to be thin following the decrease of the foam density. Therefore, several crowded thin cells must crowded together to build large microcavities, as shown in Fig. 18.

Shorter fibers contributed to a larger average cell size, which was computed in Fig. 17. The increase of cell diameter was hypothesized as coming from these overlaps. Unlike the fiber content, the fiber size had less impact on the cell regularity. These findings indicated that the cell regularity mostly depended on the amount of fibers, not the fiber length.

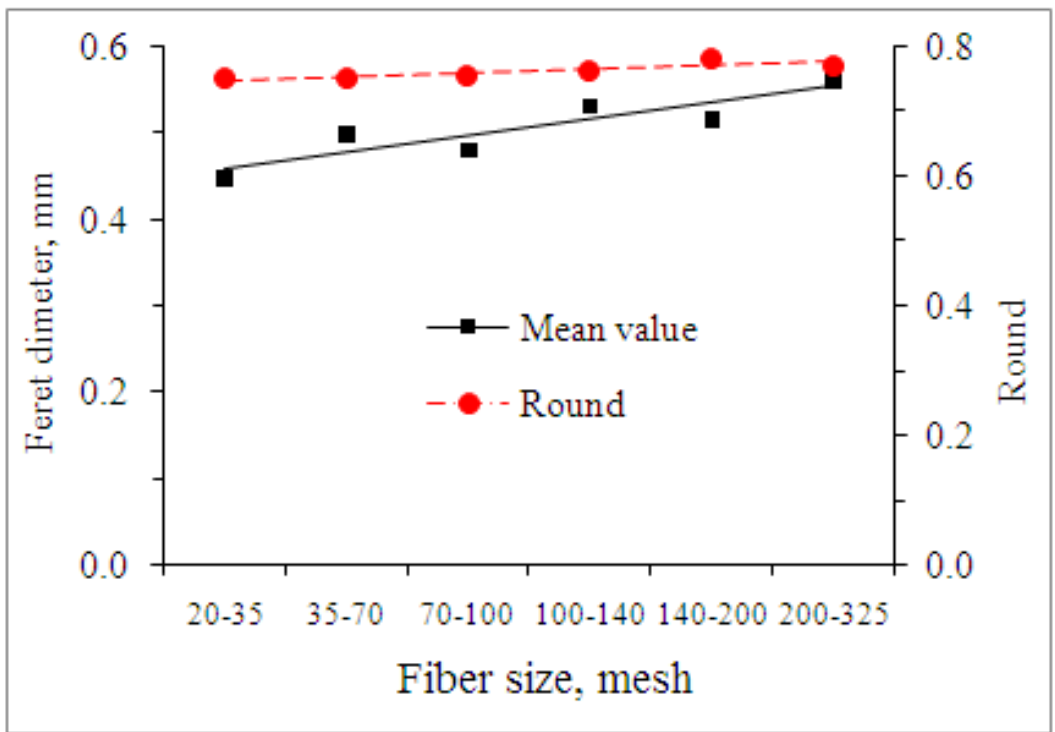

Fig. 17. Effect of fiber size on cell structures 

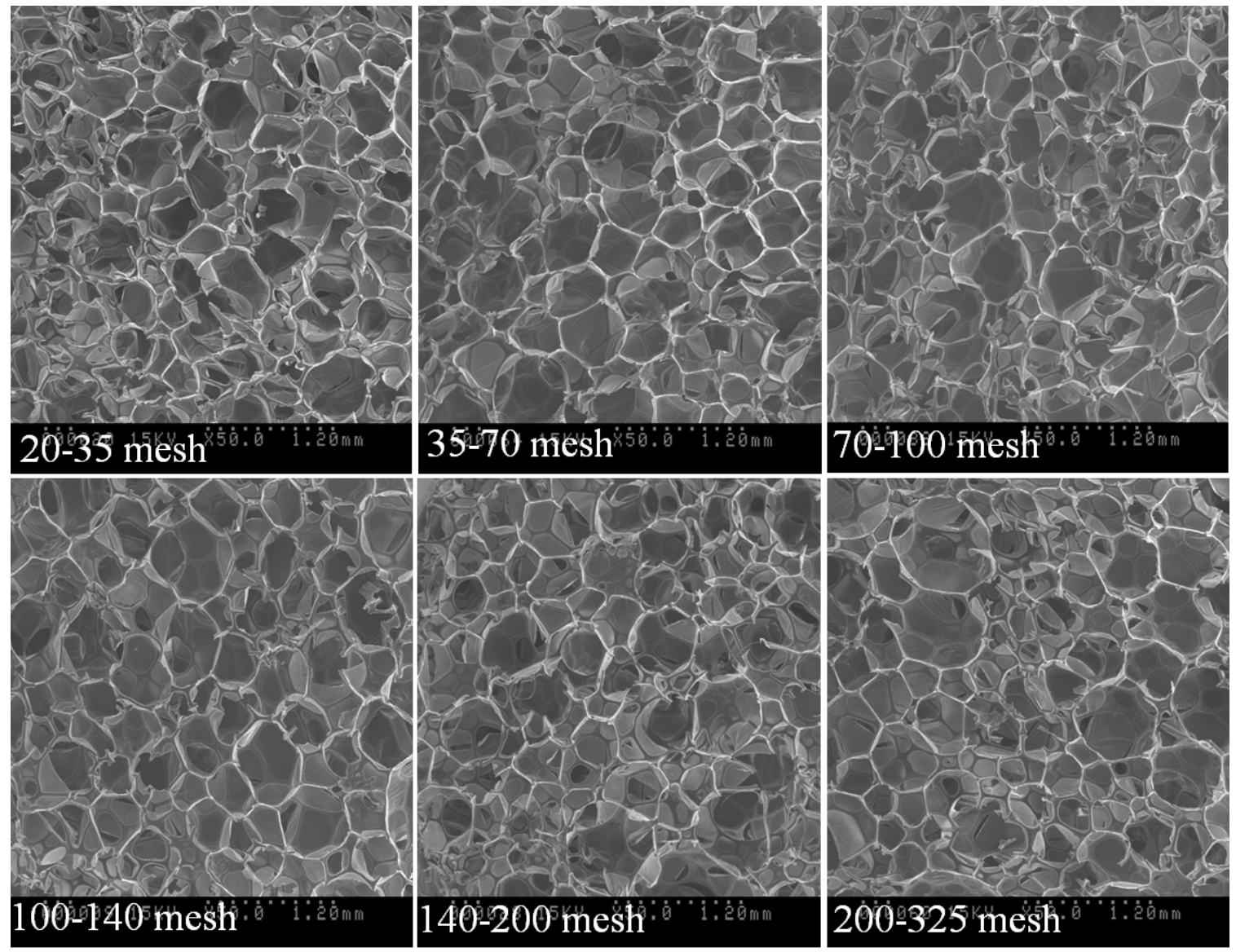

Fig. 18. SEM images of the fiber reinforced PU spray foam in different fiber size (50x)

\section{CONCLUSIONS}

PU spray foams with varying density using water as a blowing agent were prepared via a free-rise method. The amount of water affected the cell structures by increasing cell size. It was possible to prepare sprayed PU biofoams with wood fiber using a soy-based polyol. From their SEM images, wood fiber was compatible with the foam matrix due to their chemical reactions and similar polarities. The amount of fiber had significant effects on the cell structures, in particular the increase of cell size and of foam density, which was estimated from the cell walls broken and the low foam rise.

In general, long fiber showed better comparative properties, which was related to its high aspect ratio, contributing to complex structures that can act as a chain extender. Short fiber showed low aspect ratio. Such particles acted as a nucleation agent to create more cells and decreased the thickness of cell walls, since foam density decreased. The foam cells with decreased cell walls were favored in terms of overlap effects by building large microvoids, exhibiting an increase of cell size and open cell content. 


\section{ACKNOWLEDGEMENTS}

The authors would like to thank the NSERC-CRD and FPInnovations for the financial support. We would also thank Air Products and Chemicals Inc., Huntsman, and Urethane Soy Systems for their donations of materials.

\section{REFERENCES CITED}

Allen, T. (2009). "Going green: Building a greener industry with soy," Construction Executive, July 2009.

Anon. (2010). "A survey of recent chemical price trends: The potential impact of rising petrochemical prices on soy use for industrial application," Omni Tech International, Ltd.

Anon. Green Building Insulation: The environmental benefits. CUFCA technical documents. Publication by Honeywell. Page 11.

Anon. Improve energy efficiency and air sealing in above-grade walls. CUFCA technical documents. Publication by Dow Company.

Bandyopadhyay-Ghosh, S., Ghosh, S., and Sain, M. (2010). "Synthesis of soy-polyol by two step continuous route and development of soy-based polyurethane foam," Journal of Polymers and the Environment 18(3), 437-442.

Bledzki, A. K., Zhang, W., and Chate, A. (2001). "Natural-fibre-reinforced polyurethane microfoams," Composites Science and Technology 61(16), 2405-2411.

Bomberg, M. T., and Kumaran, M. K. (1999). "Use of field-applied polyurethane foams in building," Construction Technology Updates No. 32, Published by Institute for Research in Construction, National Research Council of Canada.

Brown, W. L., Matlock, P. L., Muller, L., and Ponthet, F. (2010). “Open-cell polyurethane foam and process for its manufacture," European Patent Application. No. EP2195362, Published on 16 June 2010.

Dawson, J. R., and Shortall, J. B. (1982). "The microstructure of rigid polyurethane foams," Journal of Materials Science, 17(1), 220-224.

Desai, S. D., Patel, J. V., and Sinha, V. K. (2003). "Polyurethane adhesive system from biomaterial-based polyol for bonding wood," International Journal of Adhesion and Adhesives, 23(5), 393-399.

Falke, P., Rotermund, I., Schmutzer, K., and Schmaler, K. (2001). "Production of sounddamping and energy-absorbing polyurethane foams," US Patent. No. 6316514, Issued on 13 November 2001.

Frihart, C. R. (2005). “Chapter 9: Wood adhesion and adhesives," Handbook of Wood Chemistry and Wood Composites, Rowell, R. M. (ed.), CRC Press, LCC, 215-278.

Gu, R., Sain, M. M, and Khazabi, M. (2010). "Effects of wood fiber and microclay on the performance of soyol based PU Foam," Journal of Polymers and the Environment, Under review. JOOE-456.

James, C. (2008). "2008 ISAAA Report on global status of Biotech/GM crops," International Service for the Acquisition of Agri-biotech Application. 
Jones, R. E., and Fesman, G. (1965). “Air flow measurement and its relations to cell structure, physical properties, and processibility for flexible urethane foam," Journal of Cellular Plastics 1(1), 200-216.

Li, X., Cao, H., and Zhang, Y. (2006). "Structures and physical properties of rigid polyurethane foams with water as the sole blowing agent," Science in China series B: Chemistry 49(4), 363-370.

Lohman, R. J. (2005). "Polyurethane in home construction,” The ChemQuest Group, Inc. Cincinnati, Ohio, USA. May 2005.

Meyer, H.-P. (2011). "Sustainability and biotechnology," Organic Process Research \& Development 15(1), 180-188.

Monteavaro, L. L., da Silva, E. O., Costa, A. P. O., Samios, D., Gerbase, A. E., and Petzhold, C. L. (2005). "Polyurethane networks from formiated soy polyols: Synthesis and mechanical characterization," Journal of the American Oil Chemists' Society 82(5), 365-371.

Moore, S. E., and Ference, D. M. (1998). "Polyurethane system optimization for energy efficiency," Journal of Cellular Plastics 34(2), 183-194.

Petrović, Z. S. (2008). "Polyurethanes from vegetable oils," Polymer Reviews 48(1), 109155.

Petrović, Z. S., Zhang, W., and Javni, I. (2005). "Structure and properties of polyurethanes prepared from triglyceride polyols by ozonolysis," Biomacromolecules 6(2), 713-719.

Phanopoulos, C., Marcinko, J. J., and Buckley, C. (1999). "The nature of isocyanate to wood adhesion and the locus of resin penetration," Institute of Materials Conference “Adhesion in Timber Systems”, London, UK. May 1999.

Pollack, J. W. (2004). "Soy vs. petro polyols, a life cycle comparison," GPEC 2004 paper \#37, Omni Tech International, Ltd.

Ramesh, N. S., Rasmussen, D. H., and Campbell, G. A. (1994). "The heterogeneous nucleation of microcellular foams assisted by the survival of microvoids in polymers containing low glass transition particles. Part I: Mathematical modeling and numerical simulation," Polymer Engineering \& Science 32(22), 1685-1697.

Rodrigue, D., Souici, S., and Twite-Kabamba, E. (2006). "Effect of wood powder on polymer foam nucleation," Journal of Vinyl and Additive Technology 12(1), 19-24.

Rodrigue, D., Woelfle, C., and Daigneault, L. E. (2001). "The effect of nucleating agent particle size and specific surface area on foam morphology: A new descriptor," The 3rd International Blowing Agents and Foaming Processes. Frankfurt, Germany. 1314 March 2001. Paper no 22. Published by Rapra technology.

Sherman, L. (2007). "Polyurethanes bio-based materials capture attention," Plastics Technology, December 12007.

Silva, M. C., Takahashi, J. A., Chaussy, D., Belgacem, M. N., and Silva, G. G. (2010), "Composites of rigid polyurethane foam and cellulose fiber residue," Journal of Applied Polymer Science 117(6), 3665-3672.

Sleeckx, J. (2006). "Foams form bio-based resources future persperctives," European Conference on Biorefinery Research, Helsinki, Finland, 19-20 October 2006. 
Somani, K. P., Kansara, S. S., Patel, N. K., and Rakshit, A. K. (2003). "Castor oil based polyurethane adhesives for wood-to-wood bonding," International Journal of Adhesion and Adhesives 23(4), 269-275.

Tan, S. G., and Chow, W. S. (2010). "Biobased epoxidized vegetable oils and its greener epoxy blends: A review," Polymer-Plastics Technology and Engineering 49(15), 1581-1590.

Thirumal, M., Khastgir, D., Singha, N. K., Manjunath, B. S., and Naik, Y. P. (2008). "Effect of foam density on the properties of water blown rigid polyurethane foam," Journal of Applied Polymer Science 108(3), 1810-1817.

Tylenda, E. J. (1988). "Method of preparing dimensionally stable, flexible urethane foam and the foam produced thereby," United States Patent. No. 4791146, Published on 13 December 1988.

USDA: Foreign Agricultural Service. (2011). "Oilseed: World markets and trade," February 2011 data.

USDA. (2010). "Adoption of genetically engineered crops in the U.S," Data sets.

Wake, W. C. (1978). "Theories of adhesion and uses of adhesives: A review," Polymer 19(3), 291-308.

Article submitted: June 12, 2011; Peer review completed: July 23, 2011; Revised version received and accepted: August 4, 2011; Published: August 6, 2011. 